\title{
New Aspects in Technology of Production of Raw Milk
}

\author{
Ovsyannikova Galina \\ Faculty of Technology and \\ Commodity science \\ Voronezh State Agrarian Univercity \\ named after Emperor Peter the Great \\ Voronezh, Russia \\ frauovs@yandex.ru
}

\author{
Uhina Elena \\ Faculty of Technology \\ Commodity science \\ Voronezh State Agrarian University \\ named after Emperor Peter the Great \\ Voronezh, Russia \\ uhina@bk.ru
}

\author{
Sysoeva Marina \\ Faculty of Technology \\ Commodity science \\ Voronezh State Agrarian University \\ named after Emperor Peter the Great \\ Voronezh, Russia \\ sysoevamarina@yandex.ru
}

\begin{abstract}
The authors analyse modern tendencies of development in the branch of dairy cattle breeding in the conditions of the cluster. Monitoring of effectiveness of using dairy cattle was conducted in order to form an optimal structure in the region. The productive qualities of milk of red-mottled, Simmental, Holstein, Montbeliard, Jersey, brown Swiss and black-and-white breeds were studied. The results indicate intergroup differences. According to the level of milk productivity, the animals of Holstein black-and-white breed rank first. Studies have shown that cows of Jersey breed have more population with the lowest live weight. The intensity of milk fat and protein production in comparison with Holstein animals is higher by $26.1 \%$ and $4.2 \%$, respectively. The polymorphism of the Kappacasein gene in bulls used in the Voronezh region taking into account linear affiliation was studied. Assessment of pedigree resources showed that $44,9 \%$ of the population have the homozygous $\mathrm{AA}$ genotype, $41 \%$ of heterozygous genotype $\mathrm{AB}$ and only $14 \%$ of the homozygous genotype $B B$. On average, the frequency of allele $A$ for bulls of all breeds in the population reached 0.76; the frequency of allele B-0.63. Among the bulls of Jersey, Montbeliard, Red-motley, Simmental, Holstein blackand-white breeds there are carriers of homozygous genotype of BB. The greatest number of desirable BB genotypes was revealed among bulls of Jersey and Montbeliard breeds. The researchers found that the milk obtained from the cows of the Montbeliard breed, which are the daughters of a bull containing B-allele Kappa-casein, has the best technological properties. The protein content in the milk of these cows exceeded the protein content of other genotypes by $0.08-0.12 \%$, fat content - by $0.1-0.12 \%$. Daughters born to a bull with a homozygous AA genotype have a higher level of milk production. The obtained data suggest that the genotype of a bull by casein Kappa can serve as an additional criterion for the selection of animals.
\end{abstract}

Key words - dairy cattle, cluster, appraisal, performance traits, evaluation, Kappa-casein

\section{INTRODUCTION}

In the context of the food embargo, the dairy industry of the regional agro-industrial complex is becoming increasingly competitive sector of the economy. Despite the actual lack of dynamics in the whole of Russia, the Voronezh region is increasing the production of raw milk and dairy products. The region for the seventh year in a row becomes the Russian leader in the growth of milk production.

In 2017 the Voronezh region produced 578094 tons of milk. Over the past seven years, milk production increased by $85.7 \%$, cow productivity increased by $2227 \mathrm{~kg}$ and amounted to $6143 \mathrm{~kg}$ (table 1$)$.

TABLE 1. DYNAMICS OF LIVESTOCK AND MILK PRODUCTION IN AGRICULTURAL ORGANIZATIONS IN 1996-2017 (CSO DATA)

\begin{tabular}{|c|c|c|c|c|c|}
\hline \multirow{2}{*}{ Indicator } & \multicolumn{5}{|c|}{ Year } \\
\cline { 2 - 6 } & $\mathbf{1 9 9 6}$ & $\mathbf{2 0 0 5}$ & $\mathbf{2 0 1 0}$ & $\mathbf{2 0 1 5}$ & $\mathbf{2 0 1 7}$ \\
\hline $\begin{array}{c}\text { The number of cows, } \\
\text { thousand heads }\end{array}$ & 459.2 & 85.1 & 76.9 & 83.9 & 90.7 \\
\hline Milk production, tons & 758727 & 311200 & 318509 & 475975 & 578094 \\
\hline $\begin{array}{c}\text { Milk production, kg } \\
\text { per 1 cow }\end{array}$ & 1653 & 3322 & 4265 & 5545 & 6492 \\
\hline
\end{tabular}

The increase in milk production became possible due to the creation of high-tech complexes. The necessity of industrialization of agricultural technologies in modern conditions is considered as a dialectical inevitability [1].

Along with this, in the Voronezh region one of the most effective models of improving the competitiveness of the dairy industry was the organization of the dairy cluster. 
A key direction of organizational work in the organization of the cluster was the creation of powerful modern agricultural holdings on the basis of processing enterprises and producers of commercial milk. The biological and economic potential of the region made it possible to realize the scale effect on 17 new-generation dairy mega-complexes, designed for keeping from 1.5 to 5 thousand heads of dairy herd. The global task set by the region is 30 dairy complexes, which will produce the total of 1 million tons of milk.

The most ambitious projects of the holding are "Molvest", "Company", "Don - AGRO". Availability of own dairy herds allows one to guarantee high quality of production, beginning with a stage of production of raw milk. The dairy cluster also includes small companies and farms.

Taking into account that in the Central Federal district the region takes the leading positions on production of milk, formation of the dairy cluster including producers of milk, the enterprises for its processing, distribution networks is logical. Regional specialists have high competence in the field of milk production and processing. The presence of well - known brands of dairy products in the region, as well as the leadership in Russia in the production of resource-intensive products-a serious competitive advantage for the cluster of the region.

Local conditions largely determine the characteristics of the parameters of the production process (breed of cattle, the concentration of livestock, the level of productivity, etc.). Analysis of the specifics of regional production, the use of the local information space of the regional cluster are necessary to improve the efficiency of milk production [2].

The determining factor of productivity and cost of the received production in agricultural production is a breed of animals. In dairy production, the breed of cows is a means of production and a tool of labor. When choosing for breeding these or those breeds it is necessary to take into account: biological features of animals, natural and economic conditions, technological solutions of production, features of the market.

Today the dairy herd of the Voronezh region consists of 7 breeds. When making up high-tech complexes the reorientation of the enterprises for breeding of the species of intensive type was made. It should be noted that a fundamentally new trend of the cluster is that when planning the breed composition, the decisive role began to belong to milk processors [3].

In recent years, the number of Simmental cattle, historically adapted to the conditions of the black earth region, has decreased from $80 \%$ to $9.6 \%$. The number of cattle imported from abroad of Holstein black-and-white breed increased, the share of which in 2017 amounted to $28.1 \%$ [3]. For the first time in Russia animals of Monbeliard, Jersey and brown Swiss breeds were imported. But, prevailing in the conditions of the region, there is the Voronezh type of redmottled breed, which accounts for $43.7 \%$ [4]. In recent years, this young domestic breed, approved in 1998, both in number and in productivity has occupied one of the leading places in Russia [5].
The importance of environmental and technological factors in the implementation of the genetic status of the animal is great. Using the world gene fund of cattle to obtain new highly productive populations, it is important to take into account not only hereditary characteristics, but also the conditions for their implementation. It should be remembered that highly productive individuals are the most demanding to paratypical conditions.

Purpose of the research is monitoring the effectiveness of the use of dairy cattle in order to form the optimal structure in the region is relevant. The purpose of our research is a comprehensive assessment of milk productivity, milk composition and its technological suitability for processing, obtained from cows of different breeds, bred in the conditions of intensive technologies of the Voronezh region.

\section{OBJECTS AND METHODS OF RESEARCH}

All cows of dairy herd of agricultural organizations of the region with the finished lactation for 2017 (64,7 thousand heads) were subject to the analysis of productivity. The information basis was the information about the productivity of animals from the electronic database "Selex", the materials of genomic evaluation of bulls used in the Voronezh region, the results of their own research. Main research methods: comparative, statistical and zootechnical analysis. The frequency of individual alleles was determined by the formula:

$$
\begin{aligned}
& \mathrm{P}_{\mathrm{A}}=\left(2 \mathrm{n}_{\mathrm{AA}}+\mathrm{n}_{\mathrm{AB}}\right) / 2 \mathrm{~N} \\
& \mathrm{Q}_{\mathrm{B}}=\left(2 \mathrm{n}_{\mathrm{BB}}+\mathrm{n}_{\mathrm{AB}}\right) / 2 \mathrm{~N},
\end{aligned}
$$

where $\mathrm{P}_{\mathrm{A}}$ is the allele frequency $\mathrm{A}$; $\mathrm{QB}$ is the allele frequency $\mathrm{B}$;

$\mathrm{n}_{\mathrm{AA}}, \mathrm{n}_{\mathrm{AB}}, \mathrm{n}_{\mathrm{BB}}$ - number of animals with a certain genotype, heads;

\section{$\mathrm{N}$ - total number of animals, heads.}

\section{RESULTS AND THEIR DISCUSSION}

For improvement of breeding and productive qualities of population of the region dairy cattle, breeding material of bulls-producers of the foreign selection of the dairy direction was delivered. Analyzing the competitiveness of dairy cattle of different breeds in terms of milk productivity, the leadership of Holstein black-and-white animals is noted (table 2).

TABLE 2. MILK PRODUCTIVITY OF COWS OF DIFFERENT BREEDS IN CONDITIONS OF THE VORONEZH REGION ACCORDING TO THE 2017 VALUATION [4]

\begin{tabular}{|c|c|c|c|c|c|}
\hline \multirow{2}{*}{ Breed } & \multirow{2}{*}{$\begin{array}{c}\text { Yield. } \\
\mathbf{~ k g}\end{array}$} & \multicolumn{2}{|c|}{ Milk fat } & \multicolumn{2}{c|}{ Milk protein } \\
\cline { 3 - 6 } & $\mathbf{\%}$ & $\boldsymbol{k g}$ & $\boldsymbol{\%}$ & $\boldsymbol{k g}$ \\
\hline Red-spotted & 6240 & 3.77 & 235.2 & 3.19 & 199.1 \\
\hline Simmenta & 6331 & 3.80 & 240.6 & 3.29 & 208.3 \\
\hline Black-and-white & 6090 & 3.66 & 222.9 & 3.17 & 193.0 \\
\hline $\begin{array}{c}\text { Holstein black- } \\
\text { motley }\end{array}$ & 9397 & 3.77 & 354.3 & 3.26 & 306.3 \\
\hline Montbeliard & 6980 & 3.84 & 268.0 & 3.45 & 240.8 \\
\hline Jersey & 5606 & 5.58 & 312.8 & 3.99 & 223.6 \\
\hline Brown Swiss & 6811 & 4.31 & 293.6 & 3.39 & 230.8 \\
\hline
\end{tabular}


It should be noted that the imported cows of brown Swiss, Jersey and Montbeliard breeds showed good productive qualities in the natural conditions of the Voronezh region [3].

The output per unit of live weight in absolute terms is an important indicator that characterizes the functional activity of the organism as a whole. This is, to a sufficient extent, a comprehensive indicator that allows you to determine the zootechnical and, in other equal conditions, the economic efficiency of the use of cows of the assessed breeds as a means for milk production (table.3).

Traditionally, cows with a large live weight were associated with a higher level of milk production. But in recent years it has been proved that large animals consume more feed to maintain their own livelihoods, which makes them economically less profitable [6].

Studies have shown that the most intense breed for the production of milk fat and protein is Jersey. These miniature animals produce a unique composition [7]. Holstein blackand-white cows turned out to be more intensive in terms of milk yield under the studied conditions (table 3 ).

TABLE 3. INTENSITY OF PRODUCTION PER 100 KG OF LIVE WEIGHT OF COWS OF DIFFERENT BREEDS

\begin{tabular}{|c|c|c|c|c|}
\hline \multirow{2}{*}{ Breed } & $\begin{array}{c}\text { Live } \\
\text { weight } \\
\mathbf{k g}\end{array}$ & $\begin{array}{c}\text { Milk. } \\
\boldsymbol{k g}\end{array}$ & $\begin{array}{c}\text { Milk fat. } \\
\boldsymbol{k g}\end{array}$ & $\begin{array}{c}\text { Milk protein. } \\
\boldsymbol{k g}\end{array}$ \\
\cline { 3 - 5 } & 545 & 1145 & 43.2 & 36.5 \\
\hline Red-mottled & 565 & 1120 & 42.6 & 36.9 \\
\hline Simmental & 525 & 1160 & 42.4 & 36.8 \\
\hline Black-and-white & 56.4 & 54.6 \\
\hline Holstein & 561 & 1675 & 63.1 & 40.1 \\
\hline Montbeliard & 601 & 1161 & 44.6 & 56.9 \\
\hline Jersey & 393 & 1426 & 79.6 & 42.7 \\
\hline Brown Swiss & 540 & 1261 & 54.4 & \\
\hline
\end{tabular}

Selection programs determine that the yield of milk per lactation in dairy cattle per $1 \mathrm{~kg}$ of live weight should be at least $10 \mathrm{~kg}$.as can be seen from the data in table 3 , all the livestock is intensive in terms of milk productivity. Milk yield was respectively $16.7-11.6 \mathrm{~kg}$ per $1 \mathrm{~kg}$ of live weight in dairy breeds, and 11.2-14.3 kg - in combined Simmental and brown Swiss breeds.

The analysis showed that $97 \%$ of animals in the population of the region on the content of mass fractions of fat and protein exceed the basic parameters by $30-60 \%$ [8]. The choice made in favor of the European species is justified. Milk obtained from the Montbeliard, Jersey and brown Swiss breeds is characterized by an optimal ratio of fat and protein and in its physical and chemical properties meets the highest requirements for milk intended for industrial processing.

The Voronezh region is one of the leaders in the production of dairy products. In 2017, the Voronezh region produced 34.7 thousand tons of cheese, there is a marked significant increase in its production by $15.8 \%$; butter -20.7 thousand tons $(129.2 \%)$ [9]. It should be noted that these products are produced from milk-raw materials of high technological level.
At present time, it is important to take into account the genetic structure of the breed, as already accumulated enough information about the relationship between the production characteristics and polymorphic variants of different genes in cattle $[10,11,12,13,15]$

Taking into account the current trends in cattle breeding in terms of technological properties of milk, information on the genotypes of alleles of milk proteins is a significant factor in breeding animals, which should be taken into account in breeding work, especially in the strategy of selection of bulls for the herd $[5,12]$. The introduction of genomic technologies in the livestock industry is a powerful tool for supplying processors with raw materials of guaranteed quality.

the gene locus of one of the main milk proteins - Kappacasein (CSNZ) is important. Kappa-casein is one of the fractions of casein and the gene that controls its formation in milk, has 10 allelic variants. Among them, cattle identified two most common - A and B in three different combinations of genotypes - AA, AB, BB. B-allele of the gene is associated with higher protein content and better cheese-making properties of milk $[8,13,14,16]$.

The vector of development of the breed is bulls. They raise their herds and the breed as a whole to a new level of perfection. Breeding lines are a way to convert the individual characteristics to the group and the saturation of a new breed of individual heredity [17].

TABLE 4. THE DISTRIBUTION OF THE LINES OF THE BULLS USED IN THE CONDITIONS OF THE VORONEZH REGION; THE GENOTYPE OF KAPPA-CASEIN

\begin{tabular}{|c|c|c|c|}
\hline \multirow{2}{*}{ Bull line } & \multicolumn{3}{|c|}{ CSN3 } \\
\hline & $\boldsymbol{A A}$ & $A B$ & $B B$ \\
\hline \multicolumn{4}{|c|}{ Holstein red-and-white - imported breeding $(n=30)$} \\
\hline Reflection Sovering 198998 & 3 & 8 & \\
\hline Vis Basidial 1013415 & 10 & 9 & \\
\hline \multicolumn{4}{|c|}{ Red-and-white - domestic breeding ( $\mathrm{n}=11)$} \\
\hline Reflection Sovering 198998 & 1 & 2 & 1 \\
\hline Vis Basidial 1013415 & 4 & 3 & \\
\hline \multicolumn{4}{|c|}{ Red-and-white - domestic breeding $(n=36)$} \\
\hline Reflection Sovering 198998 & 4 & 2 & 1 \\
\hline Mantic Chieftain 95679 & 8 & 6 & 2 \\
\hline Siling Trigonomic 252803 & 1 & 2 & 2 \\
\hline Vis Basidial 1013415 & 1 & 1 & \\
\hline Sunnyside Standout Twin & 6 & & \\
\hline \multicolumn{4}{|c|}{ Simmental-Austrian selection $(n=15)$} \\
\hline Postgovernment & 8 & 6 & 1 \\
\hline \multicolumn{4}{|c|}{ Montbeliard-French selection $(\mathrm{n}=10)$} \\
\hline Harmon & 1 & 1 & 3 \\
\hline Pirate & 1 & 2 & \\
\hline Ocean & & 1 & 1 \\
\hline \multicolumn{4}{|c|}{ Jersey - $(n=5)$} \\
\hline Tester & & 1 & 4 \\
\hline
\end{tabular}

Evaluation of breeding resources of bulls used in the Voronezh region for this gene showed that bulls with AA genotype predominate in the population (table. 4). The analysis of Kappa-casein gene polymorphism taking into account linear affiliation showed the following: $44.9 \%$ of the livestock have homozygous AA genotype, $41 \%$ heterozygous $\mathrm{AB}$ genotype and only $14 \%$ - homozygous $\mathrm{BB}$ genotype. The frequency of allele $\mathrm{A}$ in the average of bulls of 
all breeds in the population reached 0.76 ; the frequency of allele B-0.63. Bulls of Jersey, Montbeliard, red-motley, Simmental, Holstein black-and-white breeds have carriers of homozygous genotype of BB. In Holstein red-motley and redmotley domestic bulls with a high proportion of blood (more than $75 \%$ of the Holstein breed) this genotype is absent [7].

The greatest number of desirable BB genotypes was found among the bulls of the Jersey, Montbeliard breeds (allele B frequency was 0.9 and 0.6 ).

We have assessed the level of milk productivity and quality of milk of cows-daughters, who are descendants of bulls of monbeliard breed, used in SHP "Novomarkovskoe", with different genotypes of Kappa-casein (table 5).

TABLE 5. INDICES OF MILK PRODUCTIVITY OF COWS-DAUGHTERS BORN FROM BULLS OF MONBELIARD BREED WITH DIFFERENT GENOTYPES OF KAPPACASEIN

\begin{tabular}{|l|c|c|c|}
\hline \multicolumn{1}{|c|}{ Genotype } & n & Yield, kg & MJ, \% \\
\hline $\begin{array}{l}\text { AA (EKEDIFR 5375489171 Pirate } \\
\text { lines 11695) }\end{array}$ & 25 & $8680 \pm 209.8$ & $4.13 \pm 0.10$ \\
\hline $\begin{array}{l}\text { AБ (FELINDRAFR 2547072390 } \\
\text { Pirate lines11695) }\end{array}$ & 24 & $8470 \pm 210.1$ & $4.25 \pm 0.09$ \\
\hline $\begin{array}{l}\text { BB GRASATFR 3803078751 } \\
\text { Harmont lines) }\end{array}$ & 13 & $7810 \pm 217.8$ & $4.27 \pm 0.06$ \\
\hline
\end{tabular}

\section{CONCLUSIONS}

The research results show that the daughters of the bull EKEDI with the AA genotype have a high level of milk productivity, but lower rates of mass fractions of fat and protein. Descendants of heterozygous bull FELINDRA with genotype $\mathrm{AB}$ are characterized by high milk yield and increased milk composition. Daughters born from the bull Grasats of genotype BB have the highest rates of mass fractions of fat and protein. Milk obtained from these daughters coagulates faster under the action of rennet. Thus, the analysis allows one to consider indirectly the AA genotype of Kappa-casein as a genetic marker of higher yields, and the BB genotype as a marker of higher protein content in cow milk. It should be emphasized that for a more objective assessment, it is necessary to carry out genomic evaluation of cows-daughters directly.

At the first stage of creation of the dairy cluster, most of the projects in the region were aimed at formation of sufficient volume and quality raw of materials for processing enterprises. The cluster approach provided a stable growth trend in milk production, thousands of livestock, unique breeds, a new level of breeding, latest technological solutions and increased the investment attractiveness of the dairy industry.

\section{References}

[1] V Panfilov., S. Andreev, "Engineering of the complex technological systems in the agroindustrial complex", Materials and Raw Materials,
2018, vol. 6, No. 1, pp. 23-29. DOI 10.21603/2308 -4057 - 2018 - 1 $23-29$.

[2] V. N. Surovtsev, "Realization of regional and local advantages for sustainable development of dairy cattle breeding", Dairy and beef cattle, 2018, no. 2, pp. 12-16.

[3] G. V. Ovsyannikova, "Use of the world gene fund of dairy cattle in the creation of the raw material base of the dairy industry of the Chernozem region", Bulletin of the international Academy of cold, St. Petersburg, 2017, no. 1, pp. 7-12.

[4] Results of breeding and reproduction of farm animals in the Voronezh region on January 1, 2018, Voronezh:JSC "Plempredpriyatie" Voronezh", 2018, p. 73.

[5] I. M. Dunin, G. S. Lozovaya, A. M. Chekushkin, K. K. Adzhibekov, "Genetic potential of breeding resources of herds of red-mottled breed of dairy cattle", Dairy cattle breeding, 2015, No. 8, pp. 3-6.

[6] V. I Trukhachev., N. Z. Zlydnev, M. I. "Selionova, Selection of dairy cattle of the countries of Northern Europe: strategy, methods, results (1 part)", Dairy and beef cattle, 2016, no. 1, pp. 11-14.

[7] H. B. Jensen, N. A Poulsen., K. K. Andersen et al, "Distinct composition of bovine milk from Jersey and Holstein-Friesian cows with good, poor, or noncoagulation properties as reflected in protein genetic variations and isoforms", Journal of Dairy Science, 2012, vol. 95, no. 12, pp. 6905-6917, DOI: 10.3168 / jds.2012-5675.

[8] G. V. Ovsyannikova, N. I. Gadaeva, "Promising directions in the production sector milk capacious products in terms of milk cluster Chernozem region", Vestnik of international Academy of refrigeration, St. Petersburg, 2015, no. 4, pp. 32-37.

[9] Russian Statistical Service, Official Report, 2018, retrieved from: http://www.fedstat.EN/.free

[10] L. Samusenko, S. Khimicheva, "Genotype of cows - the basis of milk quality", Milk and dairy products. Production and sales, 2012, no. 2, pp. 17-19.

[11] O. G. Loretz, E. V. Matushkina, "Influence of the Kappa-casein genotype on the technological properties of milk", Agrarian Bulletin of the Urals, 2014, no. 3, pp. $23-26$.

[12] S. Tyulkin, R. Vafin, L. Zagidullin, T. Akhetov, A.Petrov, F. Diel "Technological properties of milk of cows with different genotypes of kappa-casein and beta-lactoglobulin", Foods and Raw Materials, 2018, vol. 6, No. 1, pp. 154-162. DOI 10.21603/2308-4057-2018-1154-162

[13] A Perna., I Intaglietta, E. Gambacorta, A. Simonetti, "The influence Of casein haplotype on quality, coagulation and yield of milk from Italy Holstein", Journal of Dairy Science, 2016, vol. 99, no. 5, pp. 3288-3294.DOI: 10.3168 / jds.2015-10463.

[14] A. Di Gregorio, A. Di Grigoli, A. Di. Trana et al, "Effects of different genotypes at the CSN3 and LGB loci on milk and cheese-making characteristics of the bovine Cinisara breed", International Dairy journal, 2017, vol. 17, pp. 1-5. DOI: 10.1016 / j.idairyj.2016.11.001.

[15] B. R. Tanaskovska, S. Srbinovska., S. Andonov et al,. "Genotipization of k-Casein in Holstein-Friesian sattle in Macedonia and its association with some milk properties", International Journal of Agriculture Innovations and Research, 2016, vol. 5, No. 2, pp. 266270 .

[16] I. A Ketto, T. M Knutsen., J Oyaas et al, "Effects of milk protein polymorphism and composition, casein micelle size and salt distribution on the milk coagulation properties in Norwegian Red cattle", International Dairy journal, 2017, vol. 70. pp. 55-64. DOI: 10.1016 / j.idairyj.2016.10.010.

[17] V. I. Gerasimov, "Use of the world gene pool of pigs at different methods of cultivation", Pig Breeding, 2013, no. 6, pp. 20-22. 